\title{
UPAYA MENINGKATKAN HASIL BELAJAR EKONOMI DENGAN MENGGUNAKAN MODEL PEMBELAJARAN TIPE KARTU ARISAN SMA NEGERI 3 PALANGKA RAYA
}

\author{
Oleh \\ Jumri*, Muhammad Jailani**
}

\begin{abstract}
ABSTRAK
Penelitian ini bertujan untuk mengetahui: (1) Mengetahui aktivitas peserta didik kelas XI-MIA 2 SMAN-3 Palangka Raya dalam pembelajaran Ekonomi dengan menggunkan model pembelajaran Kartu Arisan, (2) untuk mengetahui peningkatan hasil belajar Ekonomi peserta didik kelas XI-MIA 2 SMAN-3 Palangka Raya setelah menggunakan model pembelajaran Kartu Arisan.

Metode yang digunakan peneliti adalah menggunakan rancangan Penelitian Tindakan Kelas (PTK) yang berusaha memecahkan atau menjawab masalah yang dihadapi pada subjek penelitian. Subjek penelitian adalah seluruh peserta didik kelas XI-MIA 2 SMAN-3 Palangka Raya dengan jumlah 32 peserta didik. Teknik pengumpulan data dalam penelitian ini adalah observasi dan tes. Analisis yang digunakan yaitu analisis kualitatif dan analisis kuantitatif.

Hasil penelitian ini menunjukkan bahwa: (1) peserta didik aktif pada saat pembelajaran ekonomi menggunakan model pembelajaran Kartu Arisan. Siklus I skor rata-rata 3,62 dengan kriteria baik. Pada siklus II meningkat skor rata-rata 3,83 dengan kriteria baik, (2) ada peningkatan hasil belajar ekonomi peserta didik setelah menggunakan model pembelajaran Kartu Arisan. Terlihat dari hasil belajar peserta didik pada tes awal memperoleh nilai rata-rata 67,50 (dibawah $\mathrm{KKM} \geq 80$ ) dengan ketuntasan klasikal $21 \%$ dengan kriteria tidak tercapai. Siklus I memperoleh nilai rata-rata 75,62 dengan ketuntasan klasikal 44\% dengan kriteria tidak tercapai. Siklus II memperoleh nilai rata-rata 86,71 dengan ketuntasan klasikal $100 \%$ dengan kriteria terca pai.
\end{abstract}

(c) Universitas Muhammadiyah Palangkaraya

\section{Kata Kunci: Model Kartu Arisan, Hasil Belajar Ekonomi}

\section{PENDAHULUAN}

Menurut Undang-Undang RI. No

20 Tahun 2003 tentang Sistem Pendidikan Nasional pasal 3 (Hasbullah, 2006: 4) menyatakan bahwa Pendidikan adalah usaha sadar dan terencana untuk mewujudkan suasana belajar dan proses pembelajaran agar peserta didik dapat secara aktif mengembangkan potesi dirinya untuk memiliki kekuatan spritual keagamaan, pengendalian diri, kecerdasan akhlak mulia serta keterampilan yang diperlukan dirinya, masyarakat, bangsa dan Negara.

Pendidikan merupakan sarana penting untuk meningkatkan kualitas sumber daya manusia dalam menjamin keberlangsungan pembangunan suatu 
bangsa. Peningkatan kualitas sumber daya manusia jauh lebih mendesak untuk segera direalisasikan terutama dalam menghadapi era persaingan global. Oleh karena itu, peningkatan kualitas sumber daya manusia sejak dini merupakan hal penting yang harus dipikirkan secara sungguh-sungguh. Dengan pendidikan itulah manusia dapat menciptakan taraf hidup. Pendidikan bisa diraih dengan berbagai macam cara salah satunya pendidikan di sekolah.

Pendidikan mempunyai standar proses, seperti yang terdapat pada PP (Peraturan Pemerintah) No. 32 Tahun 2005 BAB I Pasal 1 Ayat 6 Tentang Standar Proses pendidikan yang menyebut bahwa: Standar Proses Pendidikan adalah standar nasional pendidikan yang berkaitan dengan pelaksana pembelajaran pembelajaran pada satu satuan pendidikan untuk mencapai standar kompetensikelulusan.

Seperti pada tujuan pendidikan Nasional yang tecantum dalam Undangundang Republik Indonesia Nomor 20 Tahun 2003 tentang Sistem Pendidikan Nasional yang tercantum pada Pasal 3 menyatakan bahwa: Pendidikan Nasional bertujuan untuk berkembangnya potensi peserta peserta didik agar menjadi manusia yang beriman dan bertaqwa kepada Tuhan Yang Maha Esa, berakhlak mulia, sehat, beriman, cakap, kreatif, mandiri dan warga Negara demokratis serta bertanggung jawab.

Dari pernyataan di atas, dapat disimpulkan bahwa tujuan pendidikan nasional adalah lembaga yang bertanggung jawab atas belajar dan proses pembelajaran agar peserta didik secara aktif mengembangkan potensi dirinya untuk memiliki kekuatan spiritual keagamaan, pengendalian diri, kepribadian, kecerdasan, akhlak mulia, serta keterampilan yang diperlukan oleh dirinya, masyarakat bangsa dan negara.

Pelaksanaan penelitian tindakan kelas bertujuan untuk meningkatkan kualitas dan profesional guru dalam hal pendidikan ini berdasarkan Undangundang Republik Indonesia Nomor 14 Tahun 2005 Tentang Guru Dan Dosen Pasal 8 menyatakan bahwa guru wajib memiliki kualifikasi akademik, kompetensi, sertifikat pendidik, sehat jasmani dan rohani, serta memiliki kemampuan untuk menjadikan tujuan pendidikan nasional. Sedangkan pada Pasal 10 Ayat (1) kompetensi guru yang dimaksud dalam pasal 8 meliputi kompetensi pedagogik, kompetensi kepribadian,kompetensi sosial, kompetensi profesional yang diperoleh melalui pendidikan profesi. Kegiatan pembelajaran dilakukan oleh dua pelaku, yaitu guru dan peserta didik. Perilaku guru adalah mengajar dan perilaku peserta didik adalah belajar. Pembelajaran merupakan suatu sistem, yang terdiri atas berbagai kompon yang saling berhubungan satu dengan yang lain. Komponen tersebut meliputi: tujuan, materi, metode, model dan evaluasi.

Hasil belajar yaitu perubahanperubahan yang terjadi pada diri peserta didik, baik yang menyangkut aspek kognitif, afektif, dan psikomotor sebagai hasil dari kegiatan belajar. Untuk mengetahui apakah hasil belajar yang dicapai telah sesuai dengan tujuan 
yang dikehendaki dapat diketahui melalui evaluasi. Sebagaimana dikemukakan oleh Sunal (Ahmad Susanto, 2013: 5) bahwa: Evaluasi merupakan proses penggunaan informasi untuk membuat pertimbangan seberapa efektif suatu program telah memenuhi kebutuhan peserta didik. Selain itu, dengan dilakukannya evaluasi atau penilaian ini dapat dijadikan feedback atau tindak lanjut, atau bahkan cara untuk mengukur tingkat penguasaan peserta didik.

Menurut Nana Sudjana (Dimiyanti dan Mudjiono, 2006: 191) mengemukakan bahwa: Evaluasi adalah proses memberikan atau menentukan nilai kepada objek tertentu berdasarkan suatu kriteria tertentu.

Dari pendapat di atas maka dapat disimpulkan bahwa evaluasi merupakan proses penilaian suatu objek berdasarkan kriteria tertentu, dan sistematis dalam membandingkan hasil yang dicapai dengan tolak ukur yang telah ditetapkan kemudian dibuat suatu kesimpulan dan penyusunan saran pada setiap tahap dari pelaksanaan program pembelajaran yang digunakan seseorang dalam menyampaikan materi mata pelajaran kepada peserta didik sangat menentukan dalam menyampaikan tujuan pembelajaran. Sering kita jumpai masih banyaknya proses belajar mengajar di kelas yang kurang mendorong peserta didik untuk bersemangat mengikuti pelajaran.

Keberadaan model dan media pembelajaran diperlukan untuk membantu tugas-tugas guru. Guru memiliki tugas yang sangat penting guna menciptakan kondisi pembelajaran yang efektif sehingga memungkinkan proses pembelajaran dapat dicapai tujuan yang baik. Salah satu kompetisi profesional yang harus dimiliki seorang guru adalah guru harus dapat memilih, mengembangkan dan menggunakan model pembelajaran. Hal ini penting karena dapat membantu para guru dan staf pengajar dalam menyapaikan pesan pembelajaran lebih cepat dan lebih mudah ditangkap oleh peserta didik. Model pembelajaran memiliki kekuatan-kekuatan yang positif dan sinergi yang mampu merubah sikap dan perilaku, hasilnya mereka kearah perubahan kreatif dan dinamis. Sehubungan dengan hal itu, model pembelajaran seperti Kartu Arisan sangat dibutuhkan dalam pembelajaran bukan lagi dipandang sekedar alat bantu tetapi merupakan bagian yang integral dalam sistem pendidikan dan pembelajaran.

Menurut Agus Suprijono, (2011: 54) Kartu arisan adalah salah satu pembelajaran kooperatif, dimana siswa bekerja sama dalam kelompok untuk mendiskusikan kesesuaian jawaban dari setiap pertanyaan yang keluar dari dalam gelas yang telah di kocok oleh guru. Dalam memenuhi tuntutan perkembangan jaman yang semakin maju, aspek pendidikan diharuskan membimbing dan mengarahkan peserta didik untuk menjadi aktif dan kreatif. Keaktifan peserta didik hendaklah melibatkan peserta didik itu sendiri agar secara langsung belajar dan menemukan sebuah jawaban. Seringnya rasa malu peserta didik yang muncul untuk berkomunikasi membuat kondisi kelas tidak aktif. Hal seperti ini menyebabkan 
rendahnya prestasi peserta didik. Guru hendaknya memancing keaktifan peserta didik melalui model dan media pembelajaran yang sesuai. Dalam hal ini diperlukan pembelajaran yang dapat menarik minat belajar peserta didik. Dalam menggunakan model pembelajaran haruslah benar dan tepat untuk menunjang proses belajar mengajar yang dilaksanakan oleh guru. Maka dari itu, ketepatan memilih model pembelajaran merupakan faktor yang dapat mendukung dalam sukses atau tidaknya guru mendidik peserta didik menjadi generasi penerus yang dapat dibanggakan dan diandalkan. Oleh sebab itu, guru harus benar-benar menguasai model pembelajaran yang akan diterapkan dalam proses belajar mengajar.

Model pembelajaran merupakan suatu rencana atau pola yang dapat digunakan untuk membentuk kurikulum (Rencana pembelajaran jangka panjang), merancang bahan-bahan pembelajaran, dan membimbing pembelajaran di kelas atau yang lain. Hal ini sejalan dengan Joyce (Trianto, 2007: 67) berpendapat bahwa: Model pembelajaran adalah suatu perencanaan atau suatu pola yang digunakan sebagai pedoman dalam perencanaan pembelajaran di kelasatau pembelajaran dalam turitorial dan untuk menentukan perangkat-perangkat pembelajaran termasuk di dalamnya buku-buku, film, komputer dan kurikulum.

Berdasarkan hasil observasi yang dilakukan oleh peneliti pada awal bulan Agustus sampai Awal November 2017 saat mengikuti proses pembelajaran pada peserta didik kelas XI-MIA 2 di
SMA Negeri 3 Palangka Raya menunjukkan bahwa dalam pelaksanaan kegiatan pembelajaran ekonomi, terlihat peserta didik kurang memperhatikan penjelasan guru, malas atau tidak semangat mengikuti proses pembelajaran, gugup bahkan tidak bisa menjawab pertanyaan dari guru dan melamun, terdapat sebagian peserta didik yang kesulitan dalam mengerjakan tugas yang diberikan oleh guru, sehingga berdampak pada hasil belajar peserta didik. Serta tidak terlihatnya model pembelajaran yang diterapakan sehingga pembelajaran jadi membosankan bagi peserta didik, dengan sering dilakukan cara pembelajaran sistem hapalan. Dan selain itu, berdasarkan informasi dari Guru pengampu mata pelajaran ekonomi bahwa kondisi belajar peserta didik tersebut berdampak pada hasil belajar dan sebagian peserta didik yang belum mencapai KKM (Kriteria Ketuntasan Minimun), dimana KKM yang ditentukan sebesar 80 , dari 32 peserta didik hanya 13 peserta didik yang mencapai KKM.

\section{Tabel 1}

Data peserta didik yang mencapai dan belum mencapai KKM

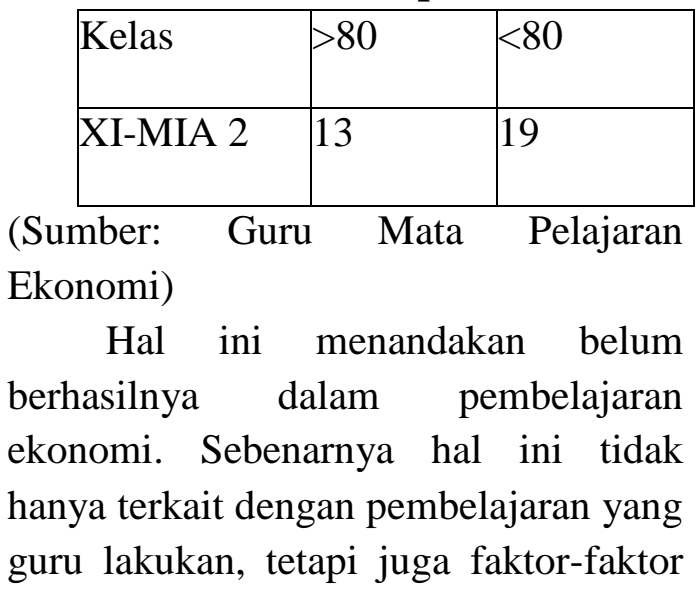


lain yang berperan dalam keberhasilan suatu pembelajaran. Ada beberapa hal yang menjadi penyebabnya, antara lain peserta didik kurang berani atau malu untuk menanyakan permasalahan yang mereka hadapi dalam kegiatan belajar mengajar, terlihat seringnya peserta didik mengobrol sendiri dan kurang aktifnya peserta didik pada saat proses belajar mengajar, tidak semangat dalam proses pembelajaran, maka dari itu diperlukan model pembelajaran yang sifatnya dapat menarik perhatian, menumbuhkan semangat dan keaktifan peserta didik, misalnya model pembelajaran Kartu Arisan, dimana dalam model ini peserta didik diharuskan tanggap, aktif dalam proses belajar mengajar dan semangat mengikuti proses pembelajaran, dikarenakan dalam model ini akan melatih kesiapan peserta didik dan saling memberikan pengetahuan dan juga memancing semangat dalam proses pembelajaran.

Maka peneliti disini berusaha mencoba untuk memecahkan suatu permasalahan dengan menggunakan model pembelajaran kartu arisan yang menuntut keaktifan peserta didik, tidak membosankan, serta tidak malas dalam proses pembelajaran. Sehingga diharapkan berdampak kepada hasil belajar yang memuaskan artinya mampu mencapai nilai KKM yakni 80 yang berlaku di sekolah SMA Negeri 3 Palangka Raya.

Dari uraian di atas, maka peneliti tertarik untuk meneliti tentang Upaya Meningkatkan Hasil Belajar Ekonomi Dengan Menggunakan Model Pembelajaran Kartu Arisan Kelas XI-
MIA 2 Di SMA Negeri 3 Palangka Raya Tahun 2017/2018.

\section{METODE PENELITIAN}

Metode Penelitian Tindakan Kelas (PTK), penelitian tindakan kelas memiliki peranan yang sangat penting dan trategis untuk meningkatkan mutu pembelajaran apabila di implementasikan dengan baik dan benar. Di implementasikan dengan baik, artinya pihak yang terlibat dalam PTK (guru) mencoba dengan sadar mengembangkan kemampuan dalam mendeteksi dan memecahkan masalahmasalah yang terjadi dalam pembelajaran di kelas melalui tindakan bermakna yang diperhitungkan dapat memecahkan masalah atau memperbaiki situasi dan kemudian secara cermat mengamati pelaksanaanya untuk mengukur tingkat keberhasilanya, diimplementasikan dengan benar, artinya sesuai dengan kaidah-kaidah PTK. Menurut Kunandar (2012: 44) menyatakan bahwa: Penelitian Tindakan Kelas (PTK) adalah suatu penelitian tindakan (action research) yang dilakukan oleh guru yang sekaligus sebagai peneliti di kelasnya atau bersama-sama dengan orang lain (kolaborasi) dengan jalan merancang, melaksanakan dan merefleksikan tindakan secara kolaboratif dan partisipatif yang bertujuan untuk memperbaiki atau meningkatkan mutu (kualitas) proses pembelajaran dikelasnya melalui tindakan (treatment) tertentu dalam suatu siklus.

PTK dilakukan dengan tujuan memperbaiki mutu praktik 
pembelajaran di kelas secara secara lebih profesional. Fokus PTK adalah pada peserta didik atau Proses Belajar Mengajar (PBM) di kelas. Tujuan utama PTK adalah untuk memecahkan permasalahan nyata yang terjadi di kelas.

Dari pengertian di atas, maka dapat diambil kesimpulan bahwa PTK merupakan penelitian yang dilakukan oleh guru dengan berkolaborasi denganpengampu mata pelajaran dan teman sejawat untuk mendapatkan suatu peningkatan hasil belajar. Kunandar (2012: 67) mengemukakan Prinsip dalam pelaksanaan PTK adalah sebagai berikut:

1. Tidak boleh mengganggu Proses Belajar Mengajar (PBM) dan tugas mengajar.

2. Tidak boleh terlalu menyita waktu.

3. Metodologi yang digunakan harus tepat dan terpercaya.

4. Masalah yang dikaji benar-benar ada dan dihadapi guru.

5. Memegang etika kerja (minta izin, membuat laporan, dan lainlain).

6. PTK bertujuan untuk memperbaiki atau meningkatkan mutu proses belajar mengajar.

7. PTK menjadi media guru untuk berfikir kritis dan sistematis.

8. PTK, menjadikan guru terbiasa melakukan aktivitas yang bernilai akademik dan ilmiah.PTK hendaknya dimulai dan permasalahan pembelajaran yang sederhana, konkret, jelas dan tajam.Pengumpulan data atau informasi dalam PTK tidak boleh terlalu banyak menyita waktu dan terlalu rumit karena dikhawatirkan dapat mengganggu tugas utama guru sebagai pengajar dan pendidik. Adapun manfaat PTK dapat dilihat dari dua aspek, yakni aspek akademis dan aspek praktis.

\section{HASIL DAN PEMBAHASAN}

Hasil belajar yang diperoleh berdasarkan hasil tes pada peserta didik kelas XI-MIA 2 SMA Negeri-3 Palangka Raya, ditemukan fenomena hasil belajar peserta didik kurang maksimal atau dibawah Kriteria Ketuntasan Minimum (KKM). Dari 32 peserta didik di kelas XI- MIA 2 SMA Negeri-3 Palangka Raya terdapat 15 pesrta didik yang belum mencapai Kriteria Ketuntasan Minimum (KKM) yaitu 80. Dalam pembelajaran ekonomi yang dilakukan peneliti pada siklus I masih ada peserta didik yang cenderung ramai sendiri. Namun setelah dilakukan refleksi pada siklus II tidak ada lagi peserta didik yang ramai sendiri. Hasil belajar ekonomi peserta didik dari siklus I ke siklus II ada yang tidak meningkat atau dengan nilai tetap seperti pada siklus I mendapat skor 80 kemudian pada siklus II mendapat skor yang sama yaitu 80. Pada siklus I pembelajaran ekonomi masih memiliki beberapa kekurangan baik itu dari aktivitas guru maupun aktivitas peserta didik. Pada siklus I guru masih belum bisa mengkondisikan kelas, guru juga kurang memberikan bimbingan dan mengelola diskusi kelompok, dan memberikan penjelasan tentang 
langkah-langkah model pembelajaran Kartu Arisan sehingga peserta didik kurang termotivasi mengikuti pelajaran dan masih ada peserta didik yang cenderung ramai sendiri.Untuk memperbaiki proses pembelajaran selanjutnya guru melakukan diskusi dengan dua orang pengamat yaitu guru dan mahasiswa. Pada siklus II guru membuat perjanjian dangan peserta didik dengan memberikan hukuman untuk peserta didik yang asik sendiri dan cenderung ramai. Pada siklus II juga guru melakukan bimbingan dan pengelolaan diskusi kelompok sehingga diskusi kelompok akan terarah dan tujuan pembelajaran tercapai aktivitas pembelajaran ekonomi di kelas XI-MIA 2 SMA Negeri-3 Palangaka Raya menjadi aktif dengan menggunakan model pembelajaran Kartu Arisan dari 32 peserta didik rata-rata hasil pengamatan aktivitas yaitu 2,85 sedangkan pada siklus II terjadi peningkatan aktivitas dengan rata-rata hasil pengamatan belajar peserta didik yaitu 3,64.

Adanya peningkatan hasil belajar dengan menggunakan model pembelajaran Kartu Arisan di kelas XIMIA 2 SMA Negeri-3 Palangaka Raya. Hal itu ditunjukkan dari hasil belajar peserta didik yang perhitungnnya didapat dari penilaian hasil post-test peserta didik siklus I dengan hasil ratarata 76,62 sedangkan ketuntasan klasikal $44 \%$ dan pada siklus II meningkat menjadi dengan hasil ratarata 86,71 sedangkan ketuntasan klasikal $100 \%$ yang terdapat peningkatan hasil belajar peserta didik.

\section{KESIMPULAN}

Dari penelitian dan pembahasan pada siklus I dan siklus II, maka dapat diambil kesimpulan sebagai berikut:

1. Aktivitas peserta didik dengan menggunakan model pembelajaran Kartu Arisan yaitu mengalami peningkatan dalam proses pembelajaran ekonomi menjadi baik, yakni peserta didik aktif dalam mengikuti proses pembelajaran, peserta didik aktif dalam pembelajaran model kartu arisan, peserta didik lebih perhatian terhadap pelajaran dan peserta didik aktif dalam berdiskusi dengan anggota kelompoknya. Hal ini dapat terlihat pada siklus I aktivitas belajar peserta didik diperoleh 2,85 (Cukup Baik) sedangkan pada siklus II diperoleh 3,64 (Baik).

2. Ada peningkatan hasil belajar ekonomi peserta didik dengan menggunakan model pembelajaran Kartu Arisan pada peserta didik kelas XI-MIA 2 SMA Negeri-3 Palangka Raya. Pada siklus I dapat diketahui perolehan hasil persentase pretest terdapat peserta didik yang tuntas 22\% (7 orang) dan peserta didik yang tidak tuntas 25 orang dengan nilai rata- rata yaitu 68 . Adapun perolehan hasil siklus I jumlah persentase hasil belajar peserta didik adalah $44 \%$ dengan nilai rata-rata 76 dan pada siklus II jumlah persentasenya menjadi $100 \%$ dengan rata-rata 87 . Ini dapat 
disimpulkan bahwa ada peningkatan hasil belajar dengan menggunakan model pembelajaran Kartu Arisan pada peserta didik kelas XI-MIA 2 SMA Negeri-3 Palangka Raya.

\section{DAFTAR PUSTAKA}

Agus Suprijono. (2011). Model-Model Pembelajaran. Jakarta:

Gramedia Pustaka Jaya.

Ahmad Susanto. (2013). Teori Belajar Dan Pembelajaran Di Sekolah Dasar. Jakarta: Kencana Prenada Media Group.

Dimiyanti Dan Mujiono. (2006). Belajar Dan Pembelajaran. Jakarta: PT Rhineka Cipta
Hasbullah. (2006). Dasar-dasar ilmu pendidikan. Jakarta: Raja Grafindo persada.

Kunandar. (2012). Langkah Mudah Penelitian Tindakan Kelas Sebagai Pengembangan Profesi Guru. Jakarta: PT Raja Grafindo Perdasa.

Trianto. (2007). Model-Model Pembelajaran Inovatif Berorientasi Konstruktivistik. Jakarta: Prestasi Pustaka.

Undang-Undang Pendidikan No 20 Tahun 2003. Tentang Sistem Pendidikan Nasional. Jakarta: Sekretariat Negara 